\title{
Asystolic cardiac arrest following liposomal amphotericin B infusion: anaphylaxis or compliment activation-related pseudoallergy?
}

\author{
George P. Drewett ${ }^{1,2^{*}}$, Ana Copaescu ${ }^{2,3}$, Joseph DeLuca ${ }^{2,4}$, Natasha E. Holmes ${ }^{1,2,5}$ and Jason A. Trubiano ${ }^{1,2,4}$
}

\begin{abstract}
Allergic reaction to liposomal amphotericin B is rare. We report a case of cardiac arrest in a 64-year-old woman following liposomal amphotericin B infusion, requiring resuscitation. We also present the results of subsequent skin prick and intradermal testing to liposomal amphotericin on the patient and three healthy controls, highlighting the need for further research into the immunopathogenesis of this reaction.
\end{abstract}

Keywords: Ambisome, LAmB, Skin prick testing, Intradermal testing, CARPA

\section{Background}

Despite its widespread use, reports of severe reactions to liposomal amphotericin B (AmBisome ${ }^{\circledR}$; LAmB), including anaphylaxis, are uncommon. Here we report a case of possible anaphylaxis or compliment activationrelated pseudoallergy (CARPA) with asystolic cardiac arrest in an adult woman shortly after delivery of LAmB.

\section{Case presentation}

A 64-year-old patient presented with a 2-week history of headache, mild photophobia, vomiting and confusion, with drenching night sweats but no fever or nuchal rigidity, and a diffuse rash involving the palms and soles. Initial investigations suggested both neurosyphilis [serum rapid plasma reagin (RPR) 1:256; Treponema pallidum particle agglutination assay (TPPA) reactive] and potentially cryptococcal meningitis (serum cryptococcal antigen low positive titre of 1:2). A CT performed on admission was unremarkable. Her past medical history

\footnotetext{
*Correspondence: george.drewett@austin.org.au

${ }^{1}$ Department of Infectious Diseases, Austin Health, Heidelberg, Australia

Full list of author information is available at the end of the article
}

was significant for hypertension, atrial fibrillation and depression, managed with Candesartan HCT 32/12.5 mg daily (withheld during admission), Sotalol $80 \mathrm{mg}$ BD, Apixaban $5 \mathrm{mg}$ BD (withheld during admission), and dothiepin $75 \mathrm{mg}$ daily, with no known drug allergy or atopy history. A lumbar puncture was performed and the patient commenced on intravenous benzylpenicillin 4-h for treatment of neurosyphilis, $\mathrm{LAmB} 4 \mathrm{mg} / \mathrm{kg}$ daily and flucytosine $25 \mathrm{mg} / \mathrm{kg} 6$ - $\mathrm{h}$ as per Australian guidelines for management of cryptococcal meningitis [1].

The patient was normotensive $(133 / 65 \mathrm{mmHg})$ at the time of commencing the infusion. Five minutes after completion of the initial LAmB infusion (total $320 \mathrm{mg}$ infused over $1 \mathrm{~h}$ ), she reported feeling lightheaded and unwell, with ascending paraesthesia in her lower limbs. An electrocardiogram was performed, demonstrating a junctional bradycardia with a heart rate of $20 \mathrm{bpm}$. Immediately thereafter, the patient lost cardiac output and cardiac monitoring demonstrated asystolic arrest. No rash or bronchospasm were noted. The patient was normoglycaemic, serum potassium measured at this time was $4.3 \mathrm{mmol} / \mathrm{L}$; serum lactate was $9.9 \mathrm{mmol} / \mathrm{L}$. Cardiopulmonary resuscitation (CPR) original author(s) and the source, provide a link to the Creative Commons licence, and indicate if changes were made. The images or other third party material in this article are included in the article's Creative Commons licence, unless indicated otherwise in a credit line to the material. If material is not included in the article's Creative Commons licence and your intended use is not permitted by statutory regulation or exceeds the permitted use, you will need to obtain permission directly from the copyright holder. To view a copy of this licence, visit http://creativecommons.org/licenses/by/4.0/. The Creative Commons Public Domain Dedication waiver (http://creativeco mmons.org/publicdomain/zero/1.0/) applies to the data made available in this article, unless otherwise stated in a credit line to the data. 


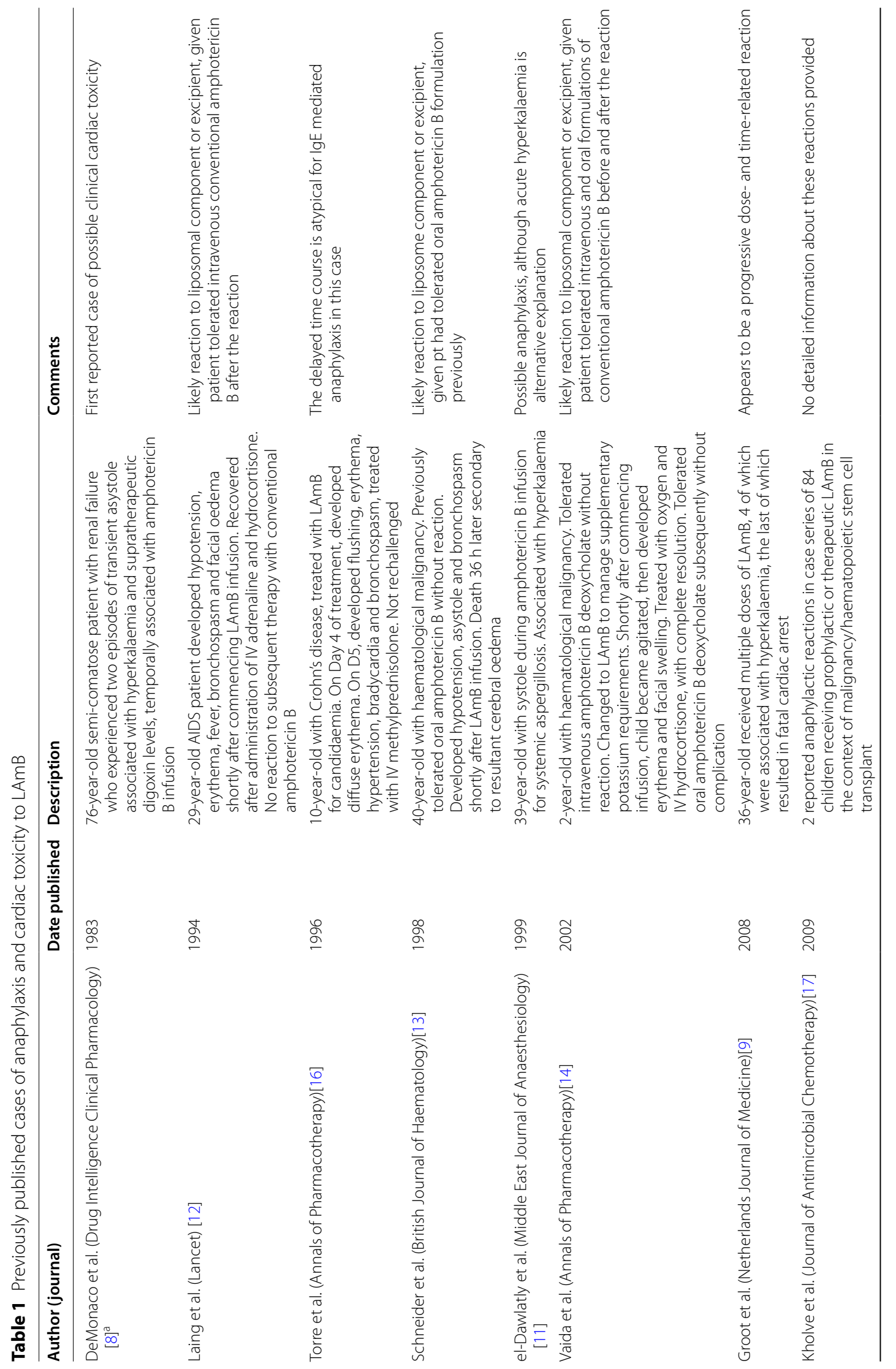


was performed for $15 \mathrm{~min}$ and two sequential doses of $1 \mathrm{mg}$ intravenous adrenaline were delivered. Return of spontaneous circulation was achieved, the patient was intubated, and transferred to the intensive care unit for ongoing monitoring and care. High sensitivity troponin I taken $4 \mathrm{~h}$ after the event was mildly elevated $(36 \mathrm{ng} / \mathrm{L}$, Reference range $<10 \mathrm{ng} / \mathrm{L}$ ), likely due to the brief period of asystole and CPR. The following morning, the patient awoke without evidence of neurological deficit and was successfully extubated.

Serial tryptase measurements taken 1 and $6 \mathrm{~h}$ after the event were $11.2 \mathrm{mcg} / \mathrm{L}$ and $6.5 \mathrm{mcg} / \mathrm{L}$ (Ref range $<11 \mathrm{mcg} / \mathrm{L}$ ), and subsequent baseline tryptase taken 6 days after the event was $6.6 \mathrm{mcg} / \mathrm{L}$, consistent with a mast-cell mediated hypersensitivity reaction based on the " $20 \%+2$ rule" [2-4]. Specific IgE for latex and chlorhexidine were negative. Subsequent transthoracic echocardiogram, myocardial perfusion imaging, and baseline ECG were normal. Lumbar puncture demonstrated a negative cerebrospinal fluid cryptococcal antigen. As such, antifungal therapy was not recommenced as the serum cryptococcal antigen was considered a likely false positive. The patient was discharged to complete a 2-week course of intravenous benzylpenicillin for neurosyphilis with clinical resolution of symptoms. At outpatient follow-up 1 month later, subsequent skin-prick testing (SPT) of LAmB at 1:10 $(4 \mathrm{mg} / \mathrm{mL})$ and intradermal testing (IDT) at 1:1000 $(0.04 \mathrm{mg} / \mathrm{ml})$ and $1: 100(0.4 \mathrm{mg} / \mathrm{ml})$ dilutions were negative. Our patient refused SPT and IDT to higher concentrations of LAmB secondary to concerns about possible reaction. IDT was also performed on three healthy controls at 1:100 concentration, without reaction.

\section{Discussion and conclusions}

Amphotericin B is a polyene antifungal agent with a broad spectrum of activity. It is indicated for the treatment of serious fungal infections, including invasive disease and cryptococcal meningitis, and infusion reactions are not uncommon [5]. LAmB is a lipid formulation of amphotericin B that alters its pharmacokinetics, and is associated with fewer nephrotoxic and infusion-related adverse effects than conventional amphotericin B (amphotericin B desoxycholate) [6].

The liposome creates a spherical vesicle around the Amphotericin B molecules, changing its pharmacokinetics to reduce toxicity by facilitating targeted administration of the Amphotericin B by binding to the fungal cell walls, while at the same time protecting human cells from exposure to Amphotericin B [7]. The excipients contained in LAmB formulations are hydrogenated soy phosphatidylcholine, distearoylphosphatidylglycerol and cholesterol (which 
form the liposome), in addition to alpha tocopherol, sucrose, disodium succinate hexahydrate, sodium hydroxide and hydrochloric acid (as buffering agents).

Severe reactions to LAmB, including anaphylaxis, are uncommon. Potential cardiac toxicity (transient asystole) associated with amphotericin B was first reported in 1983 [8]. Since then, a review of the literature has identified nine reports of anaphylaxis or cardiac toxicity attributed to LAmB (Table 1). Of note, all the cases of cardiac toxicity appeared to be dose and time dependent (occurring only after multiple sequential doses) and were associated with hyperkalaemia [8-11], for which amphotericin B has been assigned a "black box warning," however our case was normokalaemic at the time of event. Three of the reported cases of LAmB anaphylaxis were administered conventional amphotericin B either prior to or following LAmB without reaction [12-14], suggesting allergic reaction to the liposome or other excipients.

Several medications that contain liposomal preparations, including $\mathrm{LAmB}$, have been associated with "Complement activation related pseudoallergy" (CARPA) [15], a process in which complement is activated via both the classical and alternative pathway, giving rise to $\mathrm{C} 3$ and C5a anaphylatoxins and subsequent mast cell degranulation. It is possible that our patient experienced such a reaction. This also appears a possible mechanism for some of the previously published cases.

As $L A m B$ is an important agent in the management of severe fungal infections, anaphylaxis to this agent presents a challenging scenario, and understanding the reaction to be either IgE mediated or non-IgE mediated mast cell activation is a potential focus for future research.

To our knowledge, this is the first published occurrence of skin prick and intradermal testing for LAmB allergy. However, whilst SPT (at 1:10 concentration) and IDT was performed at up to 1:100 concentration, maximal non-irritating concentrations are unknown. Clinicians should be aware of the potential for either IgE or non-IgE mediated mast cell reactions in the setting of LAmB, and further research is required into the immunopathogenesis of these reactions.

\section{Acknowledgements}

We thank the patient for allowing the publication of her case.

\section{Authors' contributions}

All authors contributed to the writing of this report. All authors read and approved the final manuscript.

\section{Funding}

No specific funding was received for this report.

\section{Availability of data and materials}

All data generated during this study are included in this article.

\section{Declarations}

Ethics approval and consent to participate

The patient has given signed consent to the publication of this case.

Consent for publication

All authors consent to the publication of this manuscript.

Competing interests

The authors declare that they have no competing interests.

\section{Author details}

${ }^{1}$ Department of Infectious Diseases, Austin Health, Heidelberg, Australia. ${ }^{2}$ Department of Drug and Antibiotic Allergy Services, Austin Health, Heidelberg, Australia. ${ }^{3}$ Department of Clinical Immunology and Allergy, McGill University Health Centre, Montréal, Canada. ${ }^{4}$ Department of Medicine (Austin Health), University of Melbourne, Heidelberg, Australia. ${ }^{5}$ Data Analytics Research and Evaluation (DARE) Centre, Austin Health and University of Melbourne, Heidelberg, Australia.

Received: 13 January 2021 Accepted: 20 July 2021

Published online: 29 July 2021

\section{References}

1. Cryptococcal Meningitis. In: eTG complete [digital]. Melbourne: therapeutic guidelines limited. 2019. https://www.tg.org.au. Accessed 10 Jan 2021.

2. Valent $P$, Akin C, Arock M, Brockow K, Butterfield JH, Carter MC, et al. Definitions, criteria and global classification of mast cell disorders with special reference to mast cell activation syndromes: a consensus proposal. Int Arch Allergy Immunol. 2012;157(3):215-25.

3. Akin C. Mast cell activation syndromes. J Allergy Clin Immunol. 2017;140(2):349-55.

4. Valent P, Bonadonna P, Hartmann K, Broesby-Olsen S, Brockow K, Butterfield JH, et al. Why the $20 \%+2$ tryptase formula is a diagnostic gold standard for severe systemic mast cell activation and mast cell activation syndrome. Int Arch Allergy Immunol. 2019;180(1):44-51.

5. Hamill RJ. Amphotericin B formulations: a comparative review of efficacy and toxicity. Drugs. 2013;73(9):919-34.

6. Wingard JR, White MH, Anaissie E, Raffalli J, Goodman J, Arrieta A, L Amph/ABLC Collaborative Study Group, et al. A randomized, doubleblind comparative trial evaluating the safety of liposomal amphotericin B versus amphotericin $B$ lipid complex in the empirical treatment of febrile neutropenia. Clin Infect Dis. 2000;31(5):1155-63.

7. Stone NR, Bicanic T, Salim R, Hope W. Liposomal amphotericin B (AmBisome $\left({ }^{\circledR}\right)$ ): a review of the pharmacokinetics, pharmacodynamics, clinical experience and future directions. Drugs. 2016;76(4):485-500.

8. DeMonaco HJ, McGovern B. Transient asystole associated with amphotericin B infusion. Drug Intell Clin Pharm. 1983;17(7-8):547-8.

9. Groot OA, Trof RJ, Girbes AR, Swart NL, Beishuizen A. Acute refractory hyperkalaemia and fatal cardiac arrest related to administration of liposomal amphotericin B. Neth J Med. 2008;66(10):433-7.

10. Sanches BF, Nunes $P$, Almeida H, Rebelo M. Atrioventricular block related to liposomal amphotericin B. BMJ Case Rep. 2014. https://doi.org/10. 1136/bcr-2013-202688.

11. el-Dawlatly AA, Gomaa S, Takrouri MS, Seraj MA. Amphotericin B and cardiac toxicity - a case report. Middle East J Anaesthesiol. 1999;15(1):107-12.

12. Laing RB, Milne LJ, Leen CL, Malcolm GP, Steers AJ. Anaphylactic reactions to liposomal amphotericin. Lancet. 1994;344(8923):682.

13. Schneider P, Klein RM, Dietze L, Sohngen D, Leschke M, Heyll A. Anaphylactic reaction to liposomal amphotericin (AmBisome). $\mathrm{Br} J$ Haematol. 1998;102(4):1108-9.

14. Vaidya SJ, Seydel C, Patel SR, Ortin M. Anaphylactic reaction to liposomal amphotericin B. Ann Pharmacother. 2002;36(9):1480-1.

15. Szebeni J. Complement activation-related pseudoallergy: a new class of drug-induced acute immune toxicity. Toxicology. 2005;216(2-3):106-21. 
16. Torre I, Lopez-Herce J, Vazguez P. Anaphylactic reaction to liposomal amphotericin B in children. Ann Pharmacother. 1996;30(9):1036-7.

17. Kolve H, Ahlke E, Fegeler W, Ritter J, Jurgens H, Groll AH. Safety, tolerance and outcome of treatment with liposomal amphotericin B in paediatric patients with cancer or undergoing haematopoietic stem cell transplantation. J Antimicrob Chemother. 2009;64(2):383-7.

18. Amphotericin B liposomal: anaphylactic reaction: case report. React Wkly. 2012;(1400):8

\section{Publisher's Note}

Springer Nature remains neutral with regard to jurisdictional claims in published maps and institutional affiliations.
Ready to submit your research? Choose BMC and benefit from:

- fast, convenient online submission

- thorough peer review by experienced researchers in your field

- rapid publication on acceptance

- support for research data, including large and complex data types

- gold Open Access which fosters wider collaboration and increased citations

- maximum visibility for your research: over $100 \mathrm{M}$ website views per year

At BMC, research is always in progress.

Learn more biomedcentral.com/submissions 